\title{
Habitat size and anthropic threatens: the role of conservation areas on macroinvertebrates from tank bromeliads
}

\author{
Caroline Dias Rosaa®, Tainá Jardim Antunes ${ }^{\mathrm{b}}$, Iniwara Kurovisk Pereiraa® , Rosângela \\ Capuano Tardivoa®, Felipe Micali Nuvolonib*® \\ a Universidade Estadual de Ponta Grossa, Ponta Grossa, 84030-900, Paraná, Brasil. \\ b Universidade Federal do Sul da Bahia, Porto Seguro, 45.810-000, Bahia, Brasil.*felipe_nuvoloni@hotmail.com
}

Received: November 11, 2020 / Accepted: February 17, 2021 / Published online: May 27, 2021

\begin{abstract}
Tank bromeliads may act enhancing local biodiversity providing an important habitat for varied species. We aimed to evaluate the effect of a conservation unit and anthropic threatens on the macroinvertebrate communities associated with Aechmea distichantha (Bromeliaceae) as a model to access local ecosystems studies. The survey was conducted in the Vila Velha State Park, without severe anthropic influences and at Vila Velha Farm with the presence of Pinus spp. (an exotic/invasive species), crop plantations and a road (Ponta Grossa, Paraná, Brazil). The living organisms and bromeliad parameters were evaluated from 20 bromeliads. Total abundance was higher at anthropized area and driven by the larger size of those bromeliads. Species richness also tended to be higher at the anthropized area, although the conservation unit presented higher values when rare species were excluded. The results pointed out that bromeliads from conservation unit were under minor anthropic influences, being the presence of pines considered the main disturb in the anthropized site, which may have influenced the quality and amount of detritus resulting in distinct species composition and dominance of more tolerant taxa (Chironomidae and Ceratopogonidae). So, bromeliad mesocosm may be well suited for surveys considering anthropic influences on local ecosystems.
\end{abstract}

Keywords: Bromeliaceae, community ecology, exotic species, phytotelmata.

\section{Tamanho do habitat e ameaças antrópicas: a importância das áreas protegidas sobre macroinvertebrados de bromélias-tanque}

\begin{abstract}
Resumo
Bromélias-tanque podem atuar como promotoras da biodiversidade local abrigando uma diversa biota. Esse estudo investigou como uma unidade de conservação e uma área antropizada podem influenciar as assembleias de macroinvertebrados associadas à Aechmea distichantha Lem. (Bromeliaceae). O estudo foi conduzido no Parque Estadual de Vila Velha, local sem influências antrópicas severas e na Fazenda Vila Velha, que conta com presença de Pinus spp. (uma espécie exótica/invasora) além de outros cultivos e uma rodovia no entorno (Ponta Grossa, Paraná, Brasil). Foram amostrados os macroinvertebrados e mensurados os parâmetros estruturais de 20 bromélias. Verificou-se que as comunidades associadas às bromélias da área antropizada e da UC foram distintas, sendo a abundância total de indivíduos superior na área antropizada, possivelmente influenciada pelo maior tamanho das bromélias. A riqueza de espécies também se sobressaiu no ambiente antropizado, apesar da UC apresentar valores maiores quando as espécies raras foram excluídas da análise. Os resultados indicaram que as bromélias da unidade de conservação tiveram menor influência de ações antrópicas, sendo que o Pinus spp. pode ter influenciado a qualidade e a quantidade de detritos, resultando em distintas composições de espécies e dominância de táxons mais tolerantes (Chironomidae e Ceratopogonidae) fora da UC. Por fim, estudos envolvendo o mesocosmo bromelícola podem ser adequados para avaliar influências antrópicas sobre ecossistemas locais.
\end{abstract}

Palavras-chave: Bromeliaceae, ecologia de comunidades, espécies exóticas, fitotelmata.

\section{Introduction}

Bromeliads (Bromeliaceae) are widely distributed in Neotropical regions (Givnish et al., 2011), being many species suitable to store rainwater and nutrients from processed debris, animal excreta and carcasses, conceiving a proper microhabitat (i.e. phytotelmata) to the survival and development of a diverse aquatic and semi-aquatic biota biota, e.g., 
microorganisms, micro and macroinvertebrates (Kitching, 2001).

Studies considering tank bromeliads as mesocosms have been relevant to understand ecosystem functioning and structure (Dézerald et al., 2014), as to predict shifts in communities under different environmental conditions (e.g. canopy cover, light incidence, temperature, rainfall events, drought) and anthropic threatens (Kratina, Petermann, Marino, MacDonald \& Srivastava, 2017; Romero et al., 2020).

The composition, origin and amount of the detritus stored in the phytotelmata drive the patterns of decomposition and degradation of organic matter that will supply bromeliads trophic chain (Leroy et al., 2017). So on, the floristic composition and ecosystem integrity of the surrounding environment affect the macroinvertebrate community associated with the bromeliads, since it supplies organic matter and debris to the phytotelmata (Brouard et al., 2012; Leroy et al., 2017), and regulate the local microclimate conditions such as light incidence, humidity, and temperature (Brouard et al., 2012; Dézerald et al., 2014). Considering that native species tend to decompose more quickly than exotic ones in their home environment, known as 'home-field advantage' (Veen, Freschet, Ordonez, \& Wardle, 2015), the origin and amount of the debris in the phytotelmata may influence the nutrient absorption by bromeliads.

Aechmea distichantha Lem. (Bromeliaceae) is a native and endemic tank bromeliad from Brazil commonly found in areas of native vegetation in Campos Gerais from Paraná State, southern region (Tardivo \& Cervi, 2001). This region is composed by a vegetational mosaic in the domain of the Mixed Ombrophilous Forest, woody grassy savanna and fragments occupied by Seasonal Semi-deciduous Forest (Cervi, Von Linsingen, Hatschbach \& Ribas, 2007). Currently, native vegetation of Campos Gerais has been strongly threatened mainly due to the conversion of natural fields into crops and livestock farming, and by invasive species (Moro \& Carmo, 2007).

Pinus spp. are largely cultivated in the region and represents an ecological risk to native ecosystems due to the wind dispersion of their seeds (Abrão et al., 2015). They may spread and colonize new sites with signs of anthropic disturbance, competing with native species and resulting in the loss of local biodiversity (Zenni \& Ziller, 2011). In this context, the presence of conservation units like the Vila Velha State Park (VVSP) represent a vital effort for the protection and conservation of endemic species as well as part of Campos Gerais ecosystems (Moro \& Carmo, 2007).

Thus, we hypothesized that anthropic threatens may reduce local diversity and alters the species composition. We predict that macroinvertebrate community from bromeliads may serve as a proxy of environmental quality, indicating the negative effects of fragmentation and agriculture on the local communities. We further hypothesized that local environmental disturbances may alter the input of detritus in the phytotelmata resulting in larger bromeliads in the conservation unit. We predict that fragmentation and agriculture (lead by pine cultivation) provide a less suitable nutritional apport to bromeliads when compared to those provided by native plants at the conservation unit based in the theory of the home-field advantage.

We aimed to study the macroinvertebrate communities associated with $A$. distichantha as a model to evaluate the importance of preserved environment and anthropic threatens in local ecosystems, accessing the effects in the bromeliad parameters, species diversity, composition and abundance.

\section{Material and methods}

\section{Study area}

The samplings were carried out from 20 A. distichantha in Ponta Grossa municipality (Paraná, Brazil) in the Campos Gerais region (Figure 1), being the climate classified as $\mathrm{Cfb}$ according Köppen with 1,554 $\mathrm{mm}$ of average annual precipitation (Aparecido, Rolim, Richetti, Souza \& Johann, 2016).

As it is a manipulative study, each of the 20 bromeliads was defined as a unit sampling. The plants were selected from two parcels differing in the level of environmental disturbance, being the samplings conducted between May and June of 2007. One parcel with ten plants was located inside the Vila Velha State Park (VVSP - $25^{\circ} 20^{\prime} 48.48^{\prime \prime} \mathrm{S}$, $\left.49^{\circ} 59^{\prime} 59.59^{\prime \prime O}\right)$ which in turn is characterized as an Integral Protection Unit with 3,122.11ha (IAP, 2004). The VVSP is in the domain of the Mixed Ombrophilous Forest, a woody grassy savannah and close to the areas occupied by Seasonal Semi-deciduous Forest (Cervi et al., 2007). The parcel into VVSP where the collection was conducted is about $1,068 \mathrm{~m}$ altitude being classified as "Refúgio Vegetacional Rupestre" (rock outcrop): formations composed of rocky outcrops in the middle of a field vegetation, which accumulate organic matter in the midst of the cracks, housing a diverse biota (Cervi et al. 2007). There were no pine trees or other exotic plant species near the sampling site, and the bromeliads were exposed to the sunlight, with surrounding herbaceous vegetation.

The other parcel was in the Vila Velha Farm (VVF$25^{\circ} 21^{\prime} 27.25^{\prime \prime} \mathrm{S}, 50^{\circ} 4^{\prime} 8.94^{\prime \prime O}$ ), about $5 \mathrm{~km}$ from the parcel inside the conservation unit. The samplings were also performed on bromeliads located in a rocky outcrop occupied by a small remnant of herbaceous vegetation with invasive pine trees, surrounded by both pine and grain plantations. There was deposition of pine spurs in the substrate of the surrounding area as well as close to the bromeliads and even inside the sampled phytotelmata.

\section{Samplings}

In each parcel ten bromeliads (A. distichanta) were randomly selected and were taken measurements of their physical structure, such as: number of leaves, length of the largest leaf $(\mathrm{cm})$; diameter $(\mathrm{cm})$ - longest distance between two leaves; accumulated phytotelmata volume $(\mathrm{ml})$; temperature $\left({ }^{\circ} \mathrm{C}\right)$ of the water accumulated in the phytotelmata. Environmental parameters were also taken within a radius of 20 meters around the bromeliads, such as 
presence of exotic species, temperature of the local environment, presence of agriculture and nearby roads.

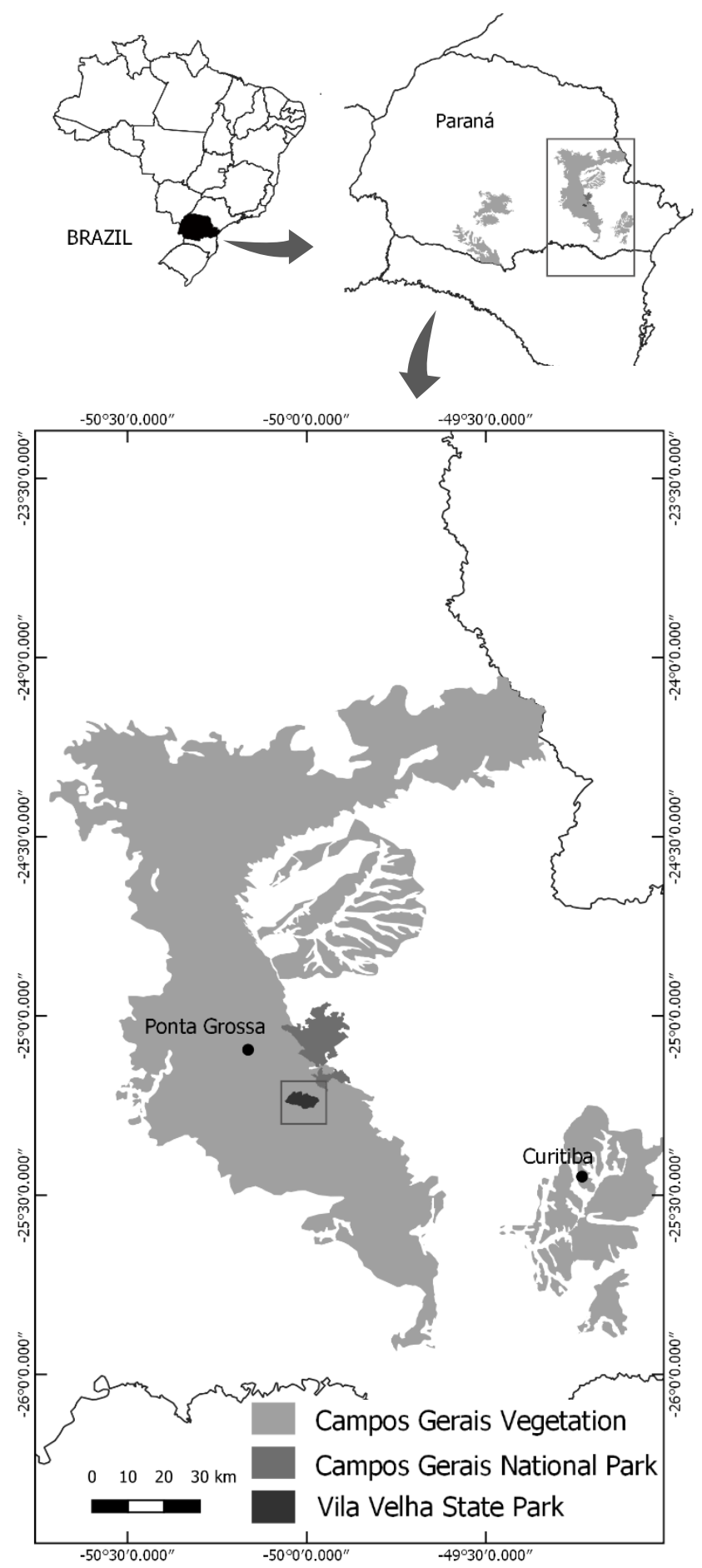

Figure 1. Distribution of Campos Gerais vegetation in the State of Paraná, and location of studied sites inside the conservation unit (Vila Velha State Park, A), and in the Vila Velha Farm (B).

\section{Data analysis}

The bromeliads were removed from the sites, and the water content were poured into a tray with a white background, after which the entire volume was stored in flasks containing $70 \%$ ethanol for fixing the invertebrates. Additional washes were performed with about $100 \mathrm{ml}$ of water, using a plastic handle, to collect possible organisms that have been trapped between the leaves. Subsequently, the plants were replanted on the spot where they were taken from. The samplings were carried out with the license 308/11 IAP.

The samples were then analyzed in the laboratory, where the macroinvertebrates were scanned and although it was not possible to reach the species level, the specimens were classified into morphotypes under a stereomicroscope and identified down to the lowest possible taxonomic level. Specimens identification weas based on literature and identification keys.

For data analysis we considered only aquatic macroinvertebrates that were found in the water tank, excluding aerial and terrestrial specimens. Aquatic macroinvertebrates are found in the water tank throughout the year due to the overlapping of generations, thus one sampling time is representative of the aquatic community (Frank \& Lounibos, 2009). On the contrary, terrestrial macroinvertebrates use tank-forming bromeliads as wet refuges, nesting sites, and/or foraging sites, so majority of the terrestrial macroinvertebrates are found more temporarily on the bromeliads (Frank \& Lounibos, 2009). Because only one sampling was performed for each site, the terrestrial and aerial macroinvertebrates were disregard from the analysis.

To evaluate the effect of protected areas on the morphological attributes of the bromeliads there were compared the variables bromeliad height, number of leaves, length of leaves, plant diameter, besides water volume and temperature of the phytotelmata between the plants located inside and outside the protected area using generalized linear models (GLMs). The effects of the protected area, anthropic threatens, and morphological attributes of the bromeliads were evaluated on the species richness using generalized linear models (GLMs). Thus, explanatory models were developed with different sets of explanatory variables (such as: variation in species richness was correlated with total species abundance, location inside and outside the conservation unit, and attributes of bromeliads) being chosen those models that presented the lowest akaike value (AIC) and the highest degree of explanation (delta weight) (Burnham \& Anderson, 1998).

The abundance of the dominant taxa was compared between the two sites using T-Test or Wilcoxon-MannWhitney (non-parametric alternative when the data set does not meet the assumptions of normality). Species composition was compared between each site using nonmetric multidimensional scaling (NMDS) based on Bray-Curtis (abundance) and Jaccard (presence/absence) dissimilarity coefficients (Clarke, 1993; Legendre \& Legendre, 1998). We used permutation multivariate analysis of variance (PERMANOVA 9999 permutations) to determine significative differences in species composition (Anderson, 2006; Anderson, Ellingsen, \& MCardle, 2006). Species abundance and values of bromeliad parameters were transformed ("hellinger" transformation) and subsequently normalized and centralized through vectored 
transformations. Additionally, to reveal the effects of these parameters on community dissimilarity, we tested whether abiotic and biotic factors adjusted to the ordination model (NMDS) by using the "Envfit" function, followed by 1.000 permutations. The analyses were performed using vegan package (Oksanen et al., 2018).

Species richness from both sampled areas was evaluated using individual-based rarefaction and extrapolation curves, which were constructed using the Hill number based in the species richness $(q=0)$, Shannon (or Shannon entropy, $q=1$ ) and Simpson diversity $(\mathrm{q}=2)$, considering that $\mathrm{q}>0$ decreases the effect of rare species in the diversity (Chao et al., 2014). Extrapolations were made from the abundance data considering between two and three times the total sample size by habitat type (Colwell et al., 2012). Rarefaction was estimated as the mean of 100 replicate bootstrapping runs to estimate $95 \%$ confidence intervals. Whenever the $95 \%$ confidence intervals did not overlap, species numbers differed significantly at $\mathrm{p}<0.05$ (Colwell et al., 2012). Rarefaction/extrapolations were computed using the iNEXT package (Hsieh, Ma, \& Chao, 2020).

\section{Results and Discussion}

Considering the morphological attributes of bromeliads, we found out a clear tendency to get bigger bromeliads outside the conservation unit. Those bromeliads had higher attributes considering diameter, height and volume when compared to those observed at the conservation unit (Table 1).

Table 1. Attributes of the bromeliads sampled at Vila Velha State Park (VVSP) and Vila Velha Farm (VVF).

\begin{tabular}{|c|c|c|c|c|}
\hline Parameter & VVSP & VVF & $\mathrm{z}$ & $\mathrm{p}$ \\
\hline Height $(\mathrm{cm})$ & $40.10 \pm 11.10$ & $48.66 \pm 7.21$ & -3.078 & 0.002 \\
\hline $\begin{array}{l}\text { Number of } \\
\text { leaves }\end{array}$ & $25.22 \pm 4.52$ & $27.33 \pm 4.21$ & -0.745 & 0.456 \\
\hline Length (cm) & $38.66 \pm 12.02$ & $36.55 \pm 6.50$ & 0.410 & 0.682 \\
\hline Dian & $27.22 \pm 7.44$ & $39.66 \pm 7.63$ & 4.410 & $<0.001$ \\
\hline Volume (mL) & $243.33 \pm 112.72$ & $411.11 \pm 208.95$ & 18.780 & $<0.001$ \\
\hline $\begin{array}{l}\text { Temperature of } \\
\text { phytotelmata } \\
\left({ }^{\circ} \mathrm{C}\right)\end{array}$ & $17.33 \pm 1.50$ & $15.44 \pm 0.53$ & -1.053 & 0.291 \\
\hline
\end{tabular}

Mean \pm standard error values, compared at Z statistics by GLM test.

It was found a total of 2.045 specimens from 32 morphotypes, considering only those found in the phytotelmata of the bromeliads. A total of 15 species and 602 individuals were found associated with bromeliads from the conservation unit, while in the Vila Velha Farm there were retrieved 27 species and 1.443 individuals (Table 2). Despite the species richness being higher outside the conservation unit, the individual based rarefaction and extrapolation curves (considering $\mathrm{q}=0$ ) indicate they are no-significative due to the overlap of confidence intervals $(95 \%)$, such as highlighted in the graphic (Figure 2A). Notwithstanding, the curves for Shannon and Simpson diversity $(\mathrm{q}=1$ and $\mathrm{q}=2)$ denoted a decreasing effect of rare species and less sensitive to the sampling effects, indicate a higher diversity in the VVSP than
VVF (Figure 2B), with significative effect considering Simpson diversity curve (Figure 2C).

Table 2. Abundance of morphotypes found at Vila Velha State Park (VVSP) and Vila Velha Farm (VVF).

\begin{tabular}{|c|c|c|c|}
\hline Taxon & Morphotype & VVSP & VVF \\
\hline \multicolumn{4}{|l|}{ Diptera } \\
\hline Culicidae & Culicidae sp. 1 & 41 & 24 \\
\hline Culicidae & Culicidae sp.2 & 1 & 0 \\
\hline Chironomidae & Chironomidae sp.1 & 130 & 557 \\
\hline Chironomidae & Chironomidae sp.2 & 0 & 144 \\
\hline Ceratopogonidae & Ceratopogonidae sp. 1 & 223 & 548 \\
\hline Ceratopogonidae & Ceratopogonidae sp.2 & 149 & 46 \\
\hline Ceratopogonidae & Ceratopogonidae sp.3 & 15 & 42 \\
\hline Ceratopogonidae & Ceratopogonidae sp.4 & 0 & 23 \\
\hline Ceratopogonidae & Ceratopogonidae sp.5 & 0 & 1 \\
\hline Ceratopogonidae & Ceratopogonidae sp.6 & 0 & 1 \\
\hline Ceratopogonidae & Ceratopogonidae sp.7 & 0 & 2 \\
\hline Tipulidae & Tipulidae sp.1 & 0 & 12 \\
\hline Psychodidae & Psychodidae sp.1 & 6 & 4 \\
\hline Psychodidae & Psychodidae sp.2 & 0 & 1 \\
\hline Ephydridae & Ephydridae sp.1 & 3 & 5 \\
\hline Dolichopodidae & Dolichopodidae sp.1 & 3 & 0 \\
\hline Empididae & Empididae sp.1 & 0 & 1 \\
\hline Canacidae & Canacidae sp.1 & 0 & 1 \\
\hline Diptera & Diptera sp.1 & 0 & 1 \\
\hline Diptera & Diptera sp. 2 & 0 & 1 \\
\hline Diptera & Diptera sp.3 & 0 & 1 \\
\hline Diptera & Diptera sp. 3 & 0 & 1 \\
\hline \multicolumn{4}{|l|}{ Coleoptera } \\
\hline Scirtidae & Scirtidae sp.1 & 14 & 14 \\
\hline Hydrophilidae & Hydrophilidae sp.1 & 5 & 3 \\
\hline Helmidae & Helmidae sp.1 & 0 & 1 \\
\hline \multicolumn{4}{|l|}{ Odonata } \\
\hline Odonata & Odonata sp.1 & 0 & 2 \\
\hline Odonata & Odonata sp. 2 & 0 & 1 \\
\hline Lepidoptera & Lepidoptera sp.1 & 1 & 0 \\
\hline Turbellaria & Tricladida sp.1 & 8 & 4 \\
\hline Crustaceae & Ostracoda sp.1 & 1 & 0 \\
\hline Tardigrada & Tardigrada sp.1 & 0 & 2 \\
\hline \multirow[t]{2}{*}{ Blattodea } & Blattodea sp.1 & 2 & 0 \\
\hline & Total & 602 & 1.443 \\
\hline
\end{tabular}

Richness was driven by two distinct set of parameters, leading by abundance and habitat structure (Table 3). Abundance was the main predictor with positive effect $(\mathrm{t}=2.535, \mathrm{p}<0.221)$. Hence, considering the predict values of richness based in the abundance there is a tendency of higher diversity at VVSP than VVF (Figure 3A). On the other hand, when isolating the influence of abundance, the net effect of habitat structure and temperature of phytotelmata over the richness become more evident, mainly considering the number of leaves and temperature $(\mathrm{t}=-2.287, \mathrm{p}<0.362$; and $\mathrm{t}=-2.348, \mathrm{p}<0.032$ ).

The assemblages located in the VVSP presented a distinct species composition from those of VVF considering both Bray-Curtis $\left(\mathrm{R}^{2}=0.310 ; \mathrm{F}_{(1,19)}=8.103 ; \mathrm{p}<0.001\right)$ and Jaccard dissimilarity indexes $\left(\mathrm{R}^{2}=0.234 ; \mathrm{F}_{(1,19)}=5.503\right.$; $\mathrm{p}<0.001)$. Both sites share $25 \%$ of the whole species 
composition, meanwhile the bromeliad from VVF seems more homogeneous among them (similarity $50 \%$ of species), unlike VVSP which mean similarity was about $36 \%$.

The NMDS ordination of species composition distinguished the sample units (bromeliads) between both sites
(VVSP and VVF; Figure 4). The analysis also retrieved that species of Diptera had a significative contribution do distinguish the composition between the sites, as well as some bromeliad parameters such as height, volume and diameter.
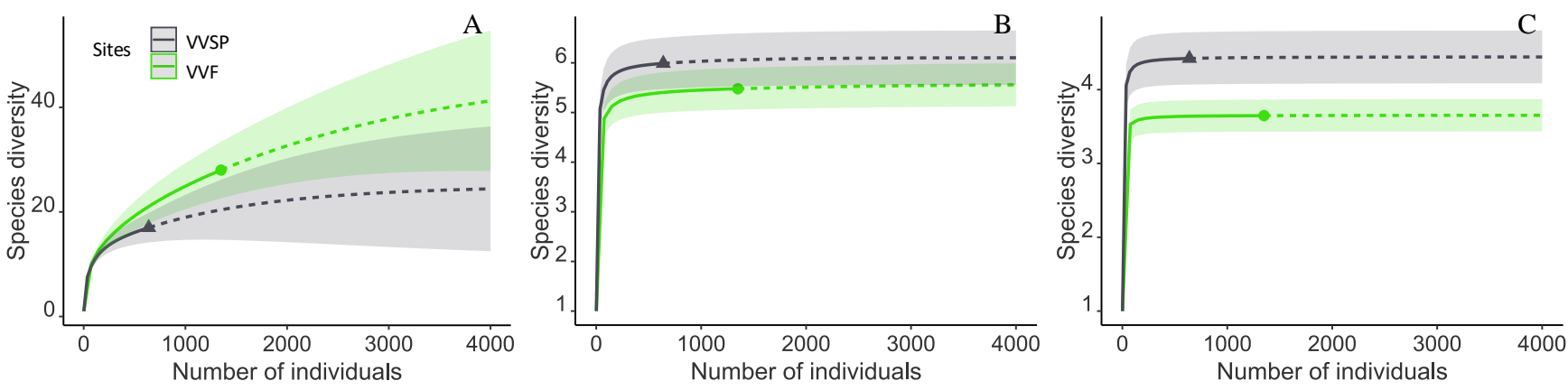

Method - interpolated - ' extrapolated

Figure 2. Comparison of sample-size-based rarefaction (solid lines) and extrapolation (dashed lines) with $95 \%$ confidence intervals for Hill numbers $q=0(A), q=1(B), q=2$ (C) for each sampling site (VVF and VVSP). The 95\% confidence intervals were obtained by a bootstrap method based on 200 replications, and all curves were extrapolated up to the base sample size of 4,000 .
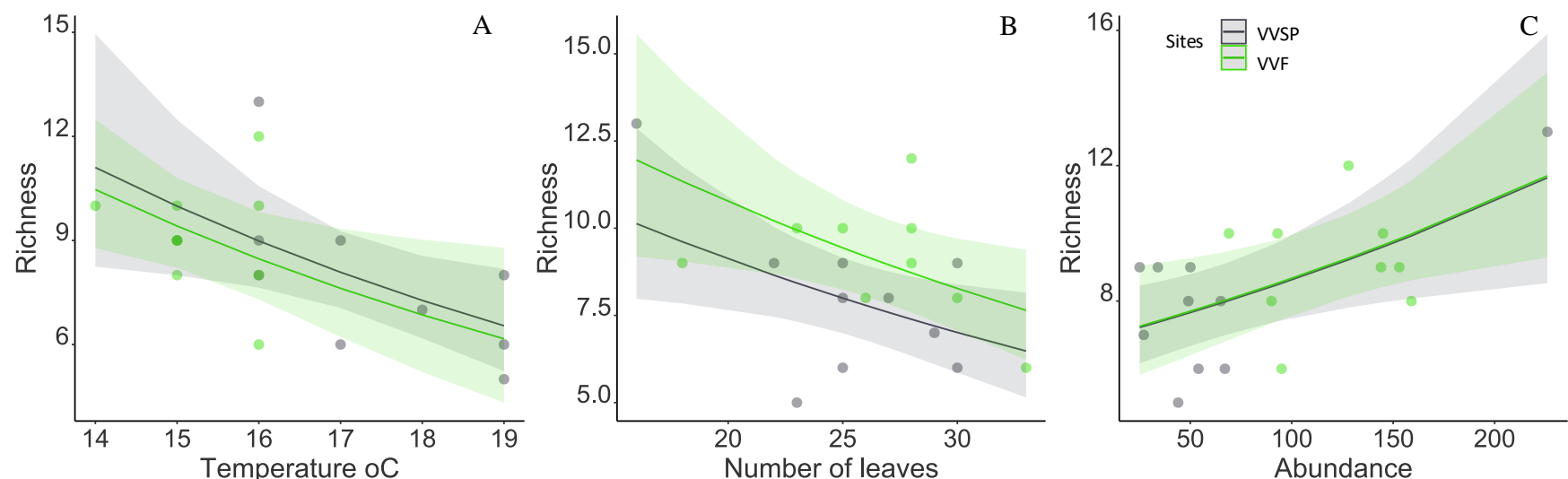

Figure 3. Effect of abundance (A), number of leaves $(B)$ and temperature $(C)$ on the species richness according to the sampling sites (results obtained from linear generalized models - GLMs).

Table 3. Summary of generalized linear models (GLMs) test for the main predictors of species richness.

\begin{tabular}{lcccc}
\hline Model & $\mathrm{R}^{2}$ & AICc & $\Delta$ AIC & Weight \\
\hline Locality, Abundance & 0.35 & 89.0 & 0.00 & 0.301 \\
Locality, Temperature & 0.30 & 89.0 & 0.01 & 0.299 \\
Locality, Leaves & 0.29 & 89.3 & 0.23 & 0.269 \\
$\begin{array}{l}\text { Locality, Leaves, } \\
\text { Temperature }\end{array}$ & 0.43 & 91.2 & 2.13 & 0.104 \\
\hline
\end{tabular}

AICc: Akaike information criterion corrected; $\triangle \mathrm{AIC}$ : difference between the AIC of a given model and the best model; wAIC: Akaike weight, measures model strength. $\mathrm{R}^{2}$ : goodness of fit for a given model.

Decoupling total abundance into the main taxa's abundance, larvae of aquatic Diptera were dominant, representing about $93 \%$ of community abundance. Their abundance was leaded by Ceratopogonidae and Chironomidae species which were more abundant in the bromeliads outside the conservation unit (Chironomidae $\mathrm{sp} 1 . \mathrm{t}=2.940$, $\mathrm{df}=$ 17.566, $\mathrm{p}=0.009$; Ceratopogonidae sp1. $\mathrm{t}=3.369$, $\mathrm{df}=$ 15.612, $\mathrm{p}=0.004$ ) accounting for $27 \%$ and $38 \%$ of total abundance, respectively. In general, our results showed that bromeliad ecosystem may represent a good model to track and study the changes in the environmental and landscape conditions as well as the level of anthropic threatens, considering that aquatic community of macroinvertebrates and the plant parameters differed between the studied sites. Although we supported the hypothesis that species composition and abundance of macroinvertebrate were distinct inside and outside the conservation unit, it was not clear enough for species diversity, since we got opposite results according to the index considered. It was highlighted by the higher values of diameter, height and volume of the phytotelmata in plants located outside the conservation unit which presented exotic/invasive plants, agriculture and roads nearby. 
Species richness was well predicted by total abundance, being also a common correlation for most studied communities and both, abundance and richness, deeply related to the habitat size (Jocque \& Field, 2014). According to theory of island biogeography (MacArthur \& Wilson, 1967), and studies with aquatic macroinvertebrate community (Petermann et al., 2015), the species-area relationship is a well-defined pattern in biological communities, being also retrieved in our study, since we observed a higher diversity in the larger bromeliads. Notwithstanding, whether considering the rarefaction/extrapolation analysis with different estimators we verified that richness may be similar or even higher in the bromeliads from VVSP.

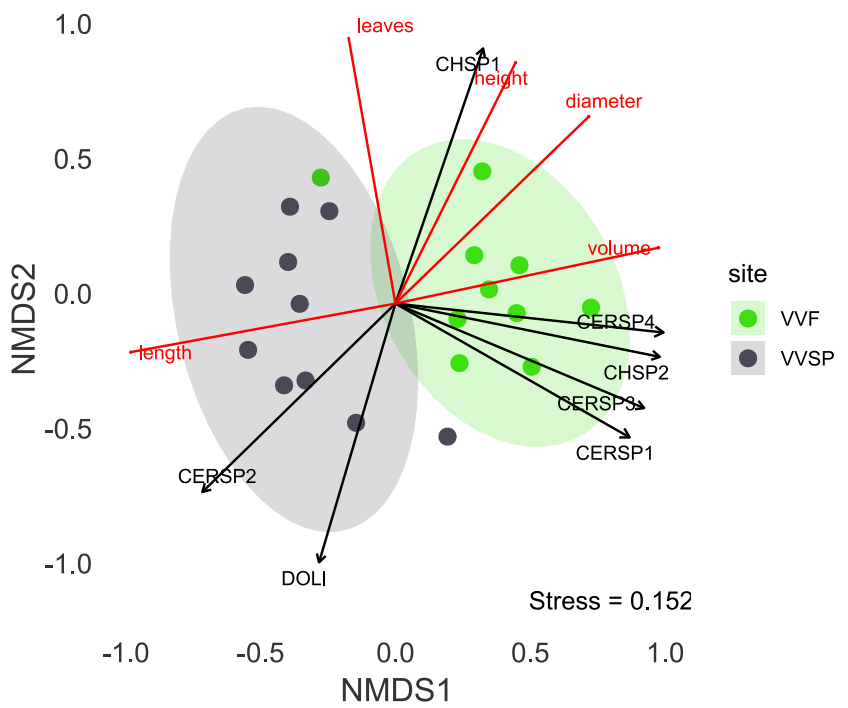

Figure 4. Non-metric multidimensional scaling (NMDS) based on species composition from the phytotelmata of bromeliads located in the Vila Velha State Park (VVSP) and Vila Velha Farm (VVF), based on Bray-Curtis dissimilarity index. Red vectors indicate bromeliad parameters, and black vectors the significative and most abundant taxa.

The presence of Pinus spp. resulted in a higher deposition of its spurs on the substrate and inside the phytotelmata of the bromeliads outside the conservation unit. Although they provide a major soil covering than naturally occurs, there is a residual from its degradation, acidifying soil $\mathrm{pH}$, with accumulation of organic matter, but with low levels of humification and high aluminum saturation (Abrão et al., 2015).

Native species tend to decompose more quickly than exotic ones in their home environments (Veen, Freschet, Ordonez, \& Wardle, 2015), as verified by Gholz et al., (2000) when comparing the decomposition rates of pine spurs with native species, being referred as 'home-field advantage'. In this way, although we hypothesized that bromeliads from the conservation unit would present higher size due to the input of detritus of native species according to the referred "home-field advantage" it was not confirmed.

Therefore, it is important to highlight that intensity and magnitude of an exotic plant on the nutrient cycling may vary according to their dominance, local assembly composition and soil type (Gholz et al., 2000). Thus, considering that the soil of Campos Gerais is nutritionally deficient (Sá, 2007), the fertilizes from surrounded plantations, and extra soil coverage and debris provided by the spurs may represent an extra input of nutrients to those bromeliads, contributing to their development (Brouard et al., 2012).

Despite the short distance between both sites (about $5 \mathrm{~km}$ ) there was a significative difference in the composition of species between them. Considering that species composition and diversity of aquatic communities are an important sign of the water quality due to the limited toleration to the environment conditioning, so many species and taxa are valuable bioindicators (Carew et al., 2013). Considering our data, Diptera accounted for more than $93 \%$ of total abundance, being the species of Chironomidae and Ceratopogonidae dominant on both sites, primarily outside the conservation unit which received an extra input of nutrients pine debris. Chironomidae are commonly reported in freshwater biomonitoring studies due to their wide abundance and diversity, being listed as bioindicators of eutrophic environments (Cazorla \& Campos, 2020), in accordance with the local conditions observed in the phytotelmata of the bromeliad close to the pines of VVF (Brouard et al., 2012).

Furthermore, the dominance of Chironomidae and Ceratopogonidae in the bromeliads outside the conservation unit is a strong indicative of environmental perturbation, acting as environmental filters for more sensitive species and hindering events of colonization (Brouard et al., 2012, Petermann et al., 2015).

\section{Conclusion}

The provision of detritus from pines and agriculture fertilizers may have had contributed to the development of bromeliads outside the conservation unit, which in turn also favored the dominance of non-specialist taxa in this environment. So, the use of bromeliads phytotelmata as a model was well suited for broad scale and landscape perspectives aiming to infer about anthropic influences on local ecosystems. The results are also likely to aggregate valuable data about living species from the phytotelmata of A. distichantha of Vila Velha State Park.

\section{References}

Abrão, S. F., da Rosa, S. F., Reinert, D. J., Reichert, J. M., Secco D., \& Ebling Â.A. (2015). Alterações químicas de um Cambissolo Húmico causadas por florestamento com Pinus taeda em área de campo natural. Floresta, 45(3), 455-464. doi: 10.5380/rf.v45i3.36103

Anderson, M. J. (2006). Distance-based tests for homogeneity of multivariate dispersions. Biometrics, 62(1), 245-253. doi: https://doi.org/10.1111/j.1541-0420.2005.00440.x

Anderson, M. J., Ellingsen, K. E., \& MCardle, B. H. (2006). Multivariate dispersion as a measure of beta diversity. Ecology Letters, 9(6), 683693. doi: 10.1111/j.1461-0248.2006.00926.x

Aparecido, L. E. D. O., Rolim, G. D. S., Richetti, J., Souza, P. S. D., \& Johann, J. A. (2016). Köppen, Thornthwaite and Camargo climate classifications for climatic zoning in the State of Paraná, Brazil. Ciência e Agrotecnologia, 40(4), 405-417. doi: 10.1590/141370542016404003916

Brouard, O., Céréghino, R., Corbara, B., Leroy, C., Pelozuelo, L., Dejean, A., \& Carrias, J. F. (2012). Understorey environments influence 
functional diversity in tank-bromeliad ecosystems. Freshwater Biology, 57(4), 815-823. doi: 10.1111/j.1365-2427.2012.02749.x

Burnham K. P., Anderson D. R. (1998) Practical Use of the InformationTheoretic Approach. In Model Selection and Inference. New York: Springer. doi: 10.1007/978-1-4757-2917-7_3

Carew, M. E., Pettigrove, V. J., Metzeling, L. \& Hoffmann, A. A. (2013). Environmental monitoring using next generation sequencing: rapid identification of macroinvertebrate bioindicator species. Frontiers in Zoology, 10(1), 45. doi: 10.1186/1742-9994-10-45

Cazorla, C. G., \& Campos, R. E. (2020). Ceratopogonidae (Diptera) Communities in a Protected Area Threatened by Urbanization. Neotropical Entomology, 49, 361-368. doi: 10.1007/s13744-020-007689

Cervi, A. C., Von Linsingen, L., Hatschbach, G., \& Ribas, O. S. (2007). A vegetação do Parque Estadual de Vila Velha, município de Ponta Grossa, Paraná, Brasil. Boletim do Museu Botânico Municipal, 69, 01-52. Available in: https://www.iat.pr.gov.br/sites/aguaterra/arquivos_restritos/files/documento/2020-

07/museu_botanico_vegetacao_pevv.pdf

Chao, A., Gotelli, N. J., Hsieh, T. C., Sande, E. L., Ma, K. H., Colwell, R. K., \& Ellison, A. M. (2014). Rarefaction and extrapolation with Hill numbers: a framework for sampling and estimation in species diversity studies. Ecological Monographs, 84(1), 45-67. doi: 10.1890/13-0133.1

Clarke, K. R. (1993). Non-parametric multivariate analyses of changes in community structure. Austral Ecology, 18(1), 117-143. doi: 10.1111/j.1442-9993.1993.tb00438.x

Colwell, R. K., Chao, A., Gotelli, N. J., Lin, S. Y., Mao, C. H., Chazdon, R. L., \& Longino J. T. (2012). Models and estimators linking individual based and sample based rarefaction, extrapolation and comparison of assemblages. Plant Ecology, 5(1), 3-21. doi: 10.1093/jpe/rtr044

Dézerald, O., Talaga, S., Leroy, C., Carrias, J. F., Corbara, B., Dejean, A., \& Céréghino, R. (2014). Environmental determinants of macroinvertebrate diversity in small water bodies: insights from tank-bromeliads. Hydrobiologia, 723(1), 77-86. doi: 10.1007/s10750-013-1464-2

Frank, J. H., \& Lounibos, L. P. (2009). Insects and allies associated with bromeliads: a review. Terrestrial Arthropod Reviews, 1(2), 125-153. doi: $10.1163 / 187498308 X 414742$

Gholz, H. L., Wedin, D. A., Smitherman, S. M., Harmon, M. E., \& Parton, W. J. (2000). Long-term dynamics of pine and hardwood litter in contrasting environments: toward a global model of decomposition. Global Change Biology, 6(7), 751-765. doi: 10.1046/j.1365-2486.2000.00349.x

Givnish, T. J., Barfuss, M. H. J., Ee, B. V., Riina, R., Schulte, K., Horres, R., Gonsiska, P. A., Jabaily, R. S., Crayn, D. M., Smith J. A. C., Winter, K., Brown, G. K., Evans, T. M., Holst, B. K., Luther, H., Till, W., Zizka, G., Berry, P. E., Sytsma, K. J. (2011). Phylogeny, adaptive radiation, and historical bio-geography in Bromeliaceae: Insights from an eight-locus plastid phylogeny. American Journal of Botany, 98(5), 872-895. doi: 10.3732/ajb.1000059

Hsieh, T. C., Ma, K. H., \& Chao, A. (2020). iNEXT: Interpolation and Extrapolation for Species Diversity. R package version 2.0.20. Available in: https://cran.r-project.org/web/packages/iNEXT/index.html

IAP, Instituto Ambiental do Paraná. (2004). Plano de Manejo do Parque Estadual de Vila Velha. Curitiba. Available in: http://www.iat.pr.gov.br/Pagina/Plano-de-Manejo-Parque-Estadual-deVila-Velha

Jocque, M., \& Field, R. (2014). Aquatic invertebrate communities in tank bromeliads: how well do classic ecological patterns apply? Hydrobiologia, 730(1), 153-166. doi: 10.1007/s10750-014-1831-7

Kitching, R. L. (2001). Food webs in phytotelmata: "bottom-up" and "topdown" explanations for community structure. Annual review of entomology, 46(1), 729-760. doi: 10.1146/annurev.ento.46.1.729

Kratina, P., Petermann, J. S., Marino, N. A., MacDonald, A. A., \& Srivastava, D. S. (2017). Environmental control of the microfaunal community structure in tropical bromeliads. Ecology and evolution, 7(5), 1627-1634. doi: $10.1002 /$ ece 3.2797

Legendre, P., \& Legendre, L. (1998). Numerical ecology (3a ed.). Amsterdam: Elsevier Science. Available in: https://books.google.com.br/books?id=6ZBOA-

iDviQC\&lpg=PP1\&ots=uz5nU8P2_i\&dq=\%20Numerical\%20ecology\% 201998\&lr\&hl=pt-

$\mathrm{BR} \& \mathrm{pg}=\mathrm{PP} 1 \# \mathrm{v}=$ onepage $\& \mathrm{q}=$ Numerical\%20ecology\%201998\&f=fals $\mathrm{e}$

Leroy, C., Corbara, B., Dézerald, O., Trzcinski, M. K., Carrias, J. F., Dejean, A., \& Céréghino, R. (2017). What drives detrital decomposition in neotropical tank bromeliads?. Hydrobiologia, 802(1), 85-95. doi: $10.1007 / \mathrm{s} 10750-017-3242-\mathrm{z}$

MacArthur, R. H., \& Wilson, E. O. (1967). The theory of island biogeography. Princeton University Press.

Moro, R. S., \& Carmo, M. R. B. (2007). A vegetação campestre nos Campos Gerais. In M. S. Melo, R. S. Moro, \& G. B. Guimarães (Orgs.), Patrimônio Natural dos Campos Gerais do Paraná (pp. 93-98). Ponta Grossa: Editora UEPG. Available in: http://ri.uepg.br:8080/riuepg/bitstream/handle/123456789/452/CAP\% c3\%8dTULO8_VegetacaoCampestreCampos.pdf?sequence=1

Oksanen, J., Blanchet, F. G., Friendly, M., Kindt, R., Legendre, P., MCglinn, D., Minchin, P. R., O'Hara, R. B., Simpson, G. L., Solymos, P., Stevens, M. H. H., Szoecs, E., \& Wagner, E. (2018). 'Vegan': community ecology package. R package version 2.4-6.

Petermann, J. S., Farjalla, V. F., Jocque, M., Kratina, P. A. MacDonald, A. M., Marino, N. A. C., Omena, P. M., Piccoli, G. C. O., Richardson, B. A., Richardson, M. J., Romero, G. Q., Videla, M., \& Srivastava, D. S. (2015). Dominant predators mediate the impact of habitat size on trophic structure in bromeliad invertebrate communities. Ecology, 96(2), 428-439. doi: 10.1890/14-0304.1

Romero, G. Q., Marino, N. A., MacDonald, A. A. M., Céréghino, R., Trzcinski, M. K., Mercado, D. A., Leroy, C., Corbara, B., Farjalla, V. F., Barberis, I. M., Dézerald, O., Hammill, E., Atwood, T. B., Picolli, G. C. O., Bautista, F. O., Carrias, J. F., Leal, J. S., Montero, G., Antiqueira, P. A. P., Freire, R., Realpe, E., Amundrud, S. L., Omena, P. M., Campos, A. B. A., Kratina, P., Gorman, E. J. O., \& Srivastava, D. S. (2020). Extreme rainfall events alter the trophic structure in bromeliad tanks across the Neotropics. Nature communications, 11(1), 1-8. doi: 10.1038/s41467-020-17036-4

Sá, M. F. M. (2007). Os solos dos Campos Gerais. In M. S. Melo, R. S. Moro, \& G. B. Guimarães. Patrimônio Natural dos Campos Gerais do Paraná (pp. 73-84). Ponta Grossa: Editora UEPG. Available in: http://ri.uepg.br/riuepg/bitstream/handle/123456789/450/CAP\%c3\%8 dTULO6_SolosCamposGerais.pdf?sequence $=1$

Tardivo, R. C., \& Cervi, A. C. (2001). Bromeliads of the State Park of Vila Velha, Ponta Grossa, Paraná, Brazil. Selbyana, 22, 68-74. Available in: https://www.jstor.org/stable/41760081

Veen, G. F., Freschet, G. T., Ordonez, A., \& Wardle, D. A. (2015). Litter quality and environmental controls of home-field advantage effects on litter decomposition. Oikos, 124(2), 187-195. doi: https://doi.org/10.1111/oik.01374

Zenni, R. D., \& Ziller, S. R. (2011). An overview of invasive plants in Brazil. Brazilian Journal of Botany, 34(3), 431-446. doi: 10.1590/S0100-84042011000300016

License: Creative Commons CC BY 4.0

This article was published with open access for distribution under the terms of the Creative Commons Attribution License, which allows unrestricted use, distribution, and reproduction in any medium, provided the original work is properly cited. 